\title{
USING AN INDOL DERIVATIVE AS COMPLEXING AGENT FOR CLOUD POINT PRECONCENTRATION AND DETERMINATION OF MAGNESIUM AND SILVER IONS IN VARIOUS SAMPLES BY FAAS
}

\author{
ARDESHIR SHOKROLLAHI ${ }^{*}$, HOSSEIN TAVALLALI ${ }^{2}$, ZOHREH MONTASERI ${ }^{2}$, KHODABAKHSH NIKNAM ${ }^{3}$ \\ ${ }^{1}$ Chemistry Department, Yasouj University, Yasouj, Iran \\ ${ }^{2}$ Department of Chemistry, Payame Noor University (PNU), Shiraz, 71365-944, Iran \\ ${ }^{3}$ Chemistry Department, Persian Gulf University, Bushehr, Iran \\ (Received: August 29, 2011 - Accepted: February 2, 2012)
}

\begin{abstract}
A very simple cloud point extraction (CPE) methodology for the preconcentration of trace amounts of silver and magnesium as a prior step for their determination by flame atomic absorption spectrometry (FAAS) has been developed. The method is based on the extraction of silver and magnesium at $\mathrm{pH} 10$ by using non-ionic surfactant Triton X-114 and 4 methyl-3-((1-H-Indol-3-iyl) (phenyl) methyl)) -1-H-Indol (MPBIM) as a complexing agent. Several important variables that affect the CPE efficiency and FAAS signal were investigated and optimized. The calibration curves, using the preconcentration system, were linear in the range of $0.007-0.200 \mu \mathrm{g} \mathrm{mL}^{-1}$ with a correlation coefficient of 0.999 . The lower limits of detection $(3 \mathrm{~s})$ obtained in the optimal conditions were $1.47 \mathrm{ng} \mathrm{mL}^{-1}$ and $3.00 \mathrm{ng} \mathrm{mL}^{-1}$ for $\mathrm{Mg}^{2+}$ and $\mathrm{Ag}^{+}$ions, respectively. The relative standard deviation for five replicate determinations of magnesium and silver at $0.133 \mu \mathrm{g} \mathrm{mL}^{-1}$ concentration level, were 1.17 and 0.97 , respectively. The proposed method was successfully applied to the ultra-trace determination of silver and magnesium in various water samples, blood serum, urine, and radiology film samples.
\end{abstract}

Keywords: Silver; Magnesium; Cloud-point extraction; Flame atomic absorption

\section{INTRODUCTION}

The determination of alkaline earth metals, particularly magnesium is of importance in environmental, biological and industrial applications. Magnesium, as a physiologically essential element, plays a significant role in the quality of drinking water. ${ }^{1}$ The relationship between magnesium deficiency and diabetes mellitus has been controversial in the medical field in recent years. ${ }^{2}$ In addition, $\mathrm{Mg}$ (II) is involved in a series of metabolism processes in the human body, including the formation of bones and cells. ${ }^{3}$

Widespread application of silver in industry, foods, drugs, beverages, photographic film production and the manufacturing of fungicides ${ }^{4,5}$ have resulted in increasing silver content of environmental water samples. In turn, owing to the toxicity of silver for many aquatic organisms even at low concentrations, serious environmental problems may occur. Therefore, simple and highly sensitive methods are required to monitor the Ag levels in water samples at ever decreasing concentrations.

A variety of methods including flame atomic absorption spectrometry (FAAS), ${ }^{6,7}$ electrothermal atomic absorption spectrometry (ETAAS), ${ }^{8,9}$ inductively coupled plasma optical emission spectrometry (ICP-OES), ${ }^{10,11}$ inductively coupled plasma mass spectroscopy (ICP-MS) $)^{12,13}$ and stripping voltammetry ${ }^{14}$ have extensively been used for trace element determination in different samples. Direct determination of trace amounts of metal ions in some samples by flame atomic absorption spectrometry is difficult because of low sensitivity. Thus, pre-concentration procedures are often required. Different techniques, such as solvent extraction, ${ }^{15,16}$ membrane filtration, ${ }^{17}$ cloud point extraction ${ }^{18,19}$ and solid phase extraction ${ }^{20,21}$ have been used to enrich the analyte and separate it from the interferences.

The principal advantages and applications of CPE have been wellestablished and identified in recent years. The use of preconcentration steps based on CPE offers a conventional alternative to more traditional extraction systems and permits the design of extraction schemes that are simple, cheap, of high efficiency and of lower toxicity than extractions that use organic solvents. To date, CPE has been used for the extraction and preconcentration of metal ions after the formation of sparingly water-soluble complexes; then the complex in the surfactant-rich phase is determined by different spectrometric methods. ${ }^{22-31}$ In the present work, we report on the results obtained from applying the $\mathrm{CPE}$ for the extraction of $\mathrm{Ag}^{+}$and $\mathrm{Mg}^{2+}$ ions from various samples and their determination by flame atomic absorption spectrometry.

\section{EXPERIMENT AND PROCEDURE}

\section{Reagents}

All solutions were prepared with double distilled water. Analytical-grade methanol, acids, and other chemicals were used (Merck, Darmstadt, Germany). A $1.0 \%(w / v)$ Triton X-114 from E. Merck was prepared by dissolving $1.0 \mathrm{~g}$ of Triton X-114 in $100 \mathrm{~mL}$ volumetric flask with stirring. All chemicals such as nitrate of $\mathrm{Mg}(\mathrm{II})$ and $\mathrm{Ag}(\mathrm{I})$ and other cations were the analytical grade purchased from Merck Company. 4 methyl-3-((1-H-Indol-3-iyl) (phenyl) methyl))-1-HIndol (MPBIM) (Fig. 1) was synthesized according to the literature. ${ }^{32}$

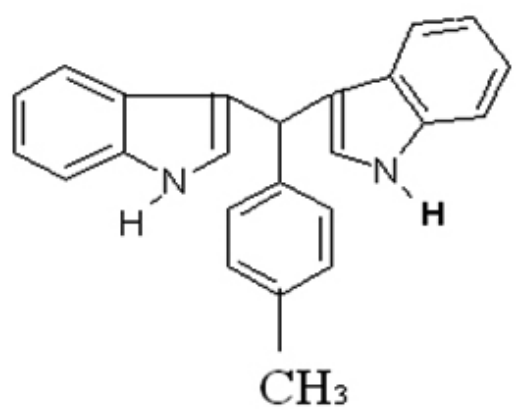

Fig. 1. Structure of 4 methyl-3-((1-H-Indol-3-iyl) (phenyl) methyl)) -1-H-Indol (MPBIM).

\section{Instrumentation}

A Sens. AA GBC (Australian) double beam atomic absorption spectrometer equipped with deuterium background correction and silver and magnesium hallow cathode lamps as the radiation source were used for absorbance measurements at wavelengths of 338 and $202 \mathrm{~nm}$, respectively. The acetylene flow rate and burner height were adjusted in order to obtain the maximum absorbance signal, while aspirating the analyte solution in methanolic nitric acid. A Fater Ltd. model B $610 \mathrm{~W}$ thermostated water bath was employed to maintain the experimental temperature and a Shimifan model CE 148 centrifuge was used to accelerate the phase separation process. A Jenway $\mathrm{pH}$ meter model 3510 was used for $\mathrm{pH}$ measurements. An Adam model 220 LA electronic analytical balance was used for weighing the solid materials. 


\section{Procedure for cloud point extraction}

A typical cloud point experiment required the following steps: $2 \mathrm{~mL}$ of a stock solution containing $\mathrm{Mg}^{2+}\left(1.0 \mu \mathrm{g} \mathrm{mL}^{-1}\right)$ and $\mathrm{Ag}^{+}\left(1.0 \mu \mathrm{g} \mathrm{mL} L^{-1}\right)$ ions, $1 \mathrm{~mL}$ of Triton X-114 (1\% w/v) and $1.5 \mathrm{~mL}$ MPBIM (1 mM ) was placed into centrifuge tube and adjusted to $\mathrm{pH} 10$ by the addition of $\mathrm{NaOH}$ and the total volume was reached to $15 \mathrm{ml}$ in a marked centrifuge tube with double distilled water. The concentration of analytes in the prepared solution was $0.133 \mu \mathrm{g} \mathrm{mL}^{-1}$. The mixture was shaken for $1 \mathrm{~min}$ and left to stand in a thermostated bath at $65^{\circ} \mathrm{C}$, for $20 \mathrm{~min}$. The separation of the phases was achieved by centrifugation at $4000 \mathrm{rpm}$ for $15 \mathrm{~min}$. The whole system was cooled in an ice bath for $5 \mathrm{~min}$ so that the surfactant rich phase would regain its viscosity. In this way, the bulk aqueous phase was easily decanted. The remaining micellar phase was dissolved to $0.5 \mathrm{~mL}$ in tetrahydrofuran (THF) ${ }^{34}$ and the $\mathrm{Mg}^{2+}$ and $\mathrm{Ag}^{+}$ions content were readily evaluated by FAAS.

\section{Sample preparation}

\section{A: Water samples}

Analysis of water samples for the determination of analyte contents was performed in the following way: About $500 \mathrm{~mL}$ of sample was passed through a sintered glass funnel and $1 \mathrm{~mL}$ concentrated $\mathrm{HNO}_{3}$ was added for elimination and decomposition of organic matter. The water samples were stored in polyethylene bottles. Then procedure given in general procedure section was applied for analysis.

\section{B: Blood serum sample}

A 5-mL portion of the clear supernatant serum obtained from a female with 34 years of age was pipetted off and treated with $5.0 \mathrm{~mL}$ of $1.2 \mathrm{M}$ trichloroacetic acid. The mixture was centrifuged at $3000 \mathrm{rpm}$, and the deproteinised supernatant was placed in a $50-\mathrm{mL}$ beaker, and the resulting solution was neutralized with $2.0 \mathrm{M} \mathrm{NaOH} \cdot{ }^{33}$ Aliquots $(7-\mathrm{mL})$ of the samples were then analyzed by the proposed method.

\section{C: Urine sample}

A $10 \mathrm{~mL}$ portion of a urine sample (or a spiked urine sample) was treated with $10 \mathrm{ml}$ of concentrated $\mathrm{HNO}_{3}(63 \%)$ and $\mathrm{HClO}_{4}(70 \%)$ mixture of $2: 1$ in a $50 \mathrm{~mL}$ beaker covered with a watch glass. The content of the beaker was heated on a hot plate $\left(100{ }^{\circ} \mathrm{C} 15 \mathrm{~min}, 150{ }^{\circ} \mathrm{C} 10 \mathrm{~min}\right)$. The watch glass was removed and the acid evaporated to dryness at $150{ }^{\circ} \mathrm{C}$. $\mathrm{HClO}_{4}(3 \mathrm{ml})$ was added to the resulting white residue and the mixture was heated at $160{ }^{\circ} \mathrm{C}$ to dryness. All heating was carried out under a hood with necessary precautions. Five milliliters of $1 \mathrm{M} \mathrm{H}_{2} \mathrm{SO}_{4}$ was added and the mixture was heated at $150{ }^{\circ} \mathrm{C}$ for 1 min. The neutralization was achieved by $\mathrm{NaOH}$ and the volume was made up to the mark in a $50 \mathrm{~mL}$ volumetric flask. ${ }^{34}$ Aliquots $(7 \mathrm{ml})$ of the resulting clear solution were analyzed according to the described procedure.

\section{D: Radiology film sample}

The waste radiographic samples were prepared for the measurement of their silver content as follows. To $20 \mathrm{ml}$ of the sample was added $10 \mathrm{ml} 3 \mathrm{M}$ nitric acid and $40 \mathrm{ml}$ water. The solution was boiled for $60 \mathrm{~min}$ until its volume was reduced to a half. The resulting solution was neutralized with sodium hydroxide solution and subsequently filtered. The filtrate and washings were diluted to $100 \mathrm{ml}$ in a volumetric flask and $2 \mathrm{ml}$ of it, used for cloud point extraction and atomic absorption measurements.

\section{RESULTS AND DISCUSSION}

The aim of this paper is to develop a simple, sensitive and available method for the preconcentration and determination of trace amounts of $\mathrm{Mg}^{2+}$ and $\mathrm{Ag}^{+}$ ions in various real samples, using flame atomic absorption spectrometry coupling with CPE. In this regard, the influence of various effective parameters including $\mathrm{pH}$, surfactant and ligand concentrations, heating time and temperature, centrifuge time and rate and the effect of electrolyte on absorbance were optimized.

\section{Effect of pH}

The formation of the metal-chelate and its chemical stability are two important factors influencing CPE. The $\mathrm{pH}$ plays a unique role in metal-chelate formation and subsequent extraction and proved to be the main parameter for CPE. Extraction yield depends on the $\mathrm{pH}$ at which complex formation is carried out. In this view, a set of similar experiments in the $\mathrm{pH}$ range of 2.0-11.0 was conducted according to the described procedure in the experimental section and the respective results are illustrated in Fig. 2. The maximum sensitivity by $\mathrm{CPE}$ was obtained at $\mathrm{pH} 10$. In more acidic solutions, deterioration of the signal occurs due to the protonation of ligand, while at $\mathrm{pH}>10$, the signal decreases and the recovery is due to precipitation of $\mathrm{Mg}^{2+}$ and $\mathrm{Ag}^{+}$ions in the form of hydroxides or ternary complexes. Also in strong alkali environments, the Triton X-114 was depreonated and the charge of surface of surfactant prevents the formation of cloud. Consequently, $\mathrm{pH}=10$ was selected for the subsequent studies.

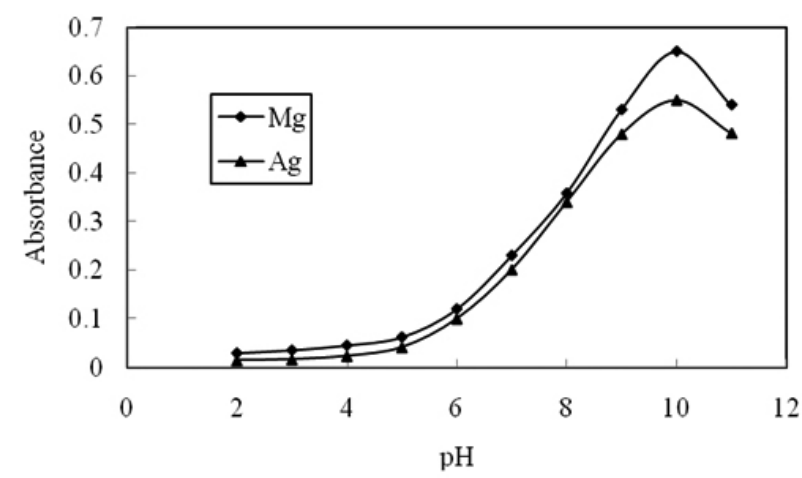

Fig. 2. Effect of $\mathrm{pH}$ of test solution on the $\mathrm{CPE}$ of magnesium and silver ions. Conditions: $\mathrm{Mg}^{2+}, 0.133 \mathrm{M}$; $\mathrm{Ag}^{+}, 0.133 \mathrm{M}$; MPBIM, $0.1 \mathrm{mM}$; Triton $\mathrm{X}-114,0.06 \%(\mathrm{w} / \mathrm{v})$.

\section{Effect of ligand concentration}

The absorbance of extracted metal ions as a function of the concentration of ligand is shown in Fig. 3. As can be seen, the increase in ligand concentration up to $0.1 \mathrm{mM}$ causes an increase in absorbance. Thus, a ligand concentration of $0.1 \mathrm{mM}$ was chosen for the optimization of other variables. It is a fact that at lower than $0.1 \mathrm{mM}$ of ligand, the complexation was not complete. The formation of charged complexes with excess amounts of ligand in the medium or remaining of excess of ligand in aqueous solution and competitive with surfactant-rich phase to form of complexes with the analytes in aqueous phase is caused the decreasing in absorbance.

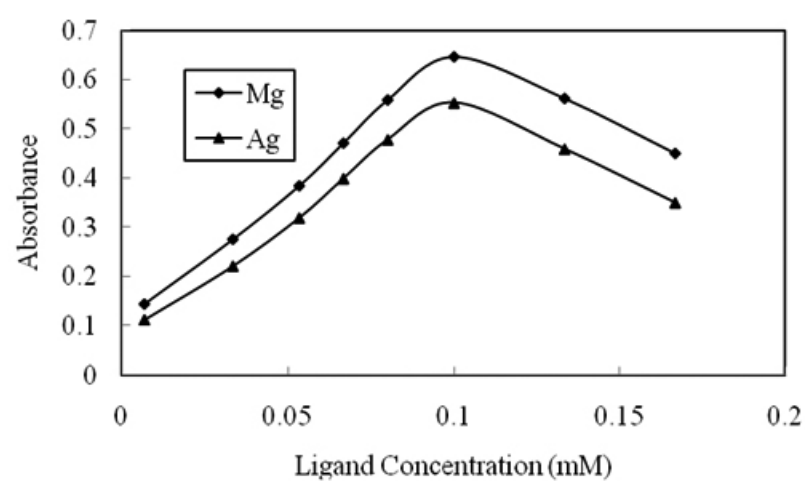

Fig. 3. Effect of MPBIM concentraction on the CPE of magnesium and silver ions. Conditions: $\mathrm{Mg}^{2+}, 0.133 \mathrm{M} ; \mathrm{Ag}^{+}, 0.133 \mathrm{M}$; Triton X-114, $0.06 \%$ $(\mathrm{w} / \mathrm{v}) ; \mathrm{pH}, 10.0$.

\section{Effect of Triton X-114 concentration}

Type and concentration of surfactant are important factors, in cloud point extraction. Triton X-114 was chosen as a proper surfactant due to its 
physicochemical characteristics, low cloud point temperature, commercial availability, relatively low price, low toxicity, its high density in the surfactantrich phase and facility for phase separation. The variation in absorbance of extracted $\mathrm{Mg}^{2+}$ and $\mathrm{Ag}^{+}$ions within the Triton $\mathrm{X}-114$ concentration range of $7 \times 10^{-3}-0.167 \%(\mathrm{w} / \mathrm{v})$ was examined and the results are shown in Fig. 4. It can be seen that quantitative extraction was obtained with an optimum Triton X-114 concentration of $0.06 \%(\mathrm{w} / \mathrm{v})$, where the highest absorbance for extracted $\mathrm{Mg}^{2+}$ and $\mathrm{Ag}^{+}$ions was obtained. For lower than $0.06 \%(\mathrm{w} / \mathrm{v})$, the preconcentration efficiency of the formed complexes was very low, since the assemblies at low concentration were probably inadequate to preconcentrate trace amounts of $\mathrm{Mg}^{2+}$ and $\mathrm{Ag}^{+}$ions. The reduction of absorbance in higher concentration than $0.06 \%(\mathrm{w} / \mathrm{v})$, is due to the remaining of some part of Triton X-114 and ligand in aqueous solution as this phase can be competitive with surfactant - rich phase for drawing analyte ions.

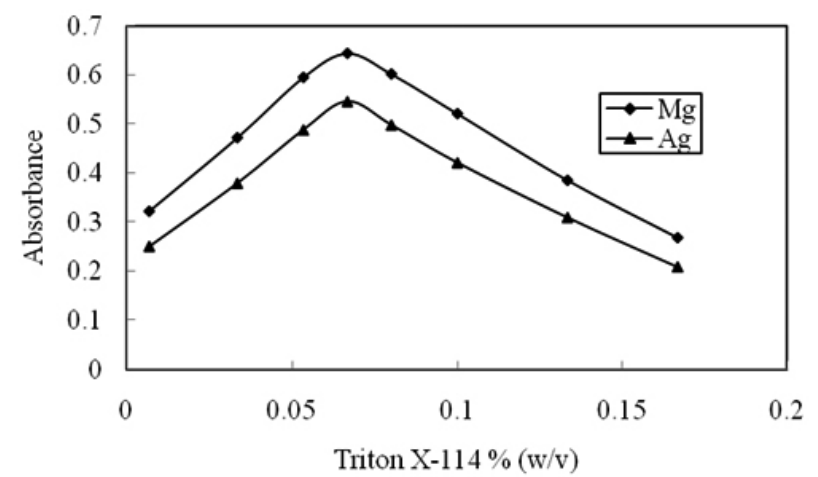

Fig.4. Effect of Triton X-114 concentration on the CPE of magnesium and silver ions. Conditions: $\mathrm{Mg}^{2+}, 0.133 \mathrm{M} \mathrm{Ag}^{+}, 0.133 \mathrm{M}$; Ligand, $0.1 \mathrm{mM}$; $\mathrm{pH}, 10.0$

\section{Effect of ionic strength}

It is known that ionic strength of the solution is one of the effective factors on cloud point extraction. In this work, the effect of $\mathrm{KNO}_{3}$ salt as electrolyte was investigated on the process. It is observed that the increasing concentration of salt to the $0.1 \mathrm{M}$ is not effective on the process, but more concentration caused a decrease in absorbance of extracted surfactant-rich phase. This effect might be explained by the additional surface charge when the salt concentration is very high.

\section{Effect of temperature and equilibrium time on CPE}

It was desirable to employ the shortest equilibration time and the lowest possible equilibration temperature as a compromise between completion of extraction and separation of phases. The dependence of extraction efficiency upon equilibration temperature and time above the cloud point in the range of $30-70{ }^{\circ} \mathrm{C}$ and 5-30 min were thoroughly optimized, respectively. It was found that holding the sample solutions for $20 \mathrm{~min}$ at $65^{\circ} \mathrm{C}$ was quite satisfactory to achieve small volume of the surfactant-rich phase, quantitative extraction and experimental convenience.

\section{Effect of centrifuge time and rate}

It is necessary to preconcentrate trace amounts of $\mathrm{Mg}^{2+}$ and $\mathrm{Ag}^{+}$ions with high efficiency in a short period of time. Therefore, $\mathrm{CPE}$ on a set of experiments of $15 \mathrm{~mL}$ sample at optimum condition by heating $65{ }^{\circ} \mathrm{C}$ and centrifuging in various rate and time further cooling in $5 \mathrm{~min}$ has been carried out. It was found that centrifugation at $4000 \mathrm{rpm}$ for $15 \mathrm{~min}$ separates two phases completely. The enrichment phase did not separate completely, in lower rate and less time centrifugation.

\section{Calibration, precision and detection limits}

Calibration graph was obtained by preconcentrating $15 \mathrm{~mL}$ of several solutions under optimum condition, containing various concentrations of analyte. The process was completed according to the general procedure section, and the absorbance of final solution was measured by FAAS. Linear relationship between the measured absorbance and concentration of $\mathrm{Mg}^{2+}$ or $\mathrm{Ag}^{+}$ions in the range $0.007-0.2 \mu \mathrm{g} \mathrm{mL}^{-1}$ was obtained. Table 1 gives the calibration parameters for the proposed CPE method including the linear ranges, the relative standard deviation obtained for 3 analyte samples subjected to the complete procedure, preconcentration and enrichment factors and the limit of detection. It is noted that a calibration curve was obtained without preconcentration in order to calculate the enrichment factor. The enrichment factor was calculated as the ratio of the slopes of calibration curve with and without preconcentration and the preconcentration factor equal to the ratio of the initially volume without preconcentration to finally volume of dissolved peconcentrated phase. ${ }^{35,36}$

Table 1. Analytical characteristics of the metod.

\begin{tabular}{|c|c|c|c|c|c|c|c|}
\hline Analyte Conditions & $\begin{array}{c}\text { Concentration range } \\
(\mu \mathrm{g} \mathrm{mL}-1)\end{array}$ & Slope & Intercept & $r^{2}$ & $\mathrm{RSD}^{\mathrm{a}}{ }^{\mathrm{a}}$ & $\begin{array}{c}\text { LOD } \\
\left(\mathrm{ng} \mathrm{mL}^{-1}\right)^{\mathrm{b}}\end{array}$ & Pf and Efe \\
\hline $\begin{array}{l}\mathrm{Ag}^{+} \text {Without } \\
\text { preconcentration }\end{array}$ & $2.8-11$ & 0.09 & 0.9676 & 0.999 & --- & --- & \multirow{2}{*}{$\begin{array}{c}\mathrm{Pf}=30 \\
\mathrm{Ef}=40.57\end{array}$} \\
\hline $\begin{array}{c}\mathrm{Ag}^{+} \text {With } \\
\text { preconcentration }(0.06 \% \\
\text { Triton X-114) }\end{array}$ & $0.007-0.2$ & 3.894 & 0.027 & 0.999 & 0.97 & 3.00 & \\
\hline $\begin{array}{l}\mathrm{Mg}^{2+} \text { Without } \\
\text { preconcentration }\end{array}$ & $5-20$ & 0.012 & 0.033 & 0.999 & --- & --- & \multirow{2}{*}{$\begin{array}{c}\mathrm{Pf}=30 \\
\mathrm{Ef}=136.09\end{array}$} \\
\hline $\begin{array}{c}\mathrm{Mg}^{2+} \text { With } \\
\text { preconcentration }(0.06 \% \\
\text { Triton } \mathrm{X}-114)^{\mathrm{d}}\end{array}$ & $0.007-0.2$ & 4.490 & 0.0491 & 0.999 & 1.17 & 1.47 & \\
\hline
\end{tabular}

${ }^{a}$ Values in parentheses are the of silver and magnesium concentrations $\left(\mu \mathrm{g} \mathrm{mL}^{-1}\right)$ for which the RSD was obtained.

${ }^{\mathrm{b}}$ Limit of detection, calculated as three times the standard deviation of the blank signal.

${ }^{\mathrm{c}}$ Standard solutions of silver and magnesium in THF medium.

${ }^{\mathrm{d}}$ Dilution of the surfactant-rich phase to $500 \mu \mathrm{l}$ of THF.

${ }^{\mathrm{e}}$ Epf and Ef are the Preconcentration factor and Enrichment factors respectively. 


\section{Interference study}

In the view of high selectivity provided by FAAS, only the interferences studied were those related to preconcentration step, i.e., those cations that may react with ligand and anions that may form complexes with $\mathrm{Mg}^{2+}$ or $\mathrm{Ag}^{+}$and decrease extraction efficiency. The study of possible interferences caused by cationic species was conducted with some ions under the experimental conditions (which was fixed concentration of $0.133 \mu \mathrm{g} \mathrm{mL}^{-1} \mathrm{of} \mathrm{Mg}^{2+}$ and $\mathrm{Ag}^{+}$, respectively). The results are shown in Table 2. There was no significant interference at a 1:1000 ratio of $\mathrm{Mg}^{2+}$ or $\mathrm{Ag}^{+}$with the cations $\mathrm{Li}^{+}, \mathrm{K}^{+}, \mathrm{Na}^{+}, \mathrm{Ag}^{+}, \mathrm{Ni}^{2+}, \mathrm{Pb}^{2+}, \mathrm{Co}^{2+}, \mathrm{Ba}^{2+}, \mathrm{Ca}^{2+}, \mathrm{Zn}^{2+}, \mathrm{Cr}^{3+}$ (for $\mathrm{Mg}^{2+}$ ) and $\mathrm{Li}^{+}, \mathrm{K}^{+}, \mathrm{Na}^{+}, \mathrm{Ni}^{2+}, \mathrm{Mg}^{2+}, \mathrm{Ca}^{2+}, \mathrm{Pb}^{2+}, \mathrm{Zn}^{2+}$ (for $\mathrm{Ag}^{+}$) and also the same condition at a ratio of 1:500 $\mathrm{Mg}^{2+}$ or $\mathrm{Ag}^{+}$with the ions $\mathrm{Cu}^{2+}, \mathrm{Mn}^{2+}, \mathrm{Cd}^{2+}, \mathrm{Fe}^{3+}$, $\mathrm{Al}^{3+}\left(\right.$ for $\mathrm{Mg}^{2+}$ ) and $\mathrm{Cu}^{2+}, \mathrm{Mn}^{2+}, \mathrm{Cd}^{2+}, \mathrm{Al}^{3+}, \mathrm{Co}^{2+}, \mathrm{Hg}^{2+}, \mathrm{CH}_{3} \mathrm{COO}^{-}\left(\right.$for $\mathrm{Ag}^{+}$).

Table 2. Effect of the interference ions on the recovery of the examined metal ions.

\begin{tabular}{|c|c|c|}
\hline $\begin{array}{l}\text { Interference/ analyte } \\
\text { ratio }\end{array}$ & Ion & Analyte \\
\hline 1000 & 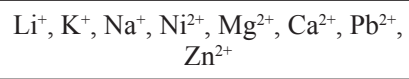 & \multirow[t]{2}{*}{$\mathrm{Ag}^{+}$} \\
\hline 500 & $\begin{array}{c}\mathrm{Cu}^{2+}, \mathrm{Mn}^{2+}, \mathrm{Cd}^{2+}, \mathrm{Al}^{3+}, \mathrm{Co}^{2+}, \mathrm{Hg}^{2+}, \\
\mathrm{CH}_{3} \mathrm{COO}^{-}\end{array}$ & \\
\hline 1000 & $\begin{array}{c}\mathrm{Li}^{+}, \mathrm{K}^{+}, \mathrm{Na}^{+}, \mathrm{Ag}^{+}, \mathrm{Ni}^{2+}, \mathrm{Pb}^{2+}, \mathrm{Co}^{2+} \\
\mathrm{Ba}^{2+}, \mathrm{Ca}^{2+}, \mathrm{Zn}^{2+}, \mathrm{Cr}^{3+}\end{array}$ & \multirow{2}{*}{$\mathrm{Mg}^{2+}$} \\
\hline 500 & $\mathrm{Cu}^{2+}, \mathrm{Mn}^{2+}, \mathrm{Cd}^{2+}, \mathrm{Fe}^{3+}, \mathrm{Al}^{3+}$ & \\
\hline
\end{tabular}

Table 3. Characteristics of the standard addition curves of $\mathrm{Mg}^{2+}$ and $\mathrm{Ag}^{+}$ions and recovery of them in water sample.

\begin{tabular}{|c|c|c|c|c|c|c|c|}
\hline Analyte & Samples & Slope & Intercept & $\mathrm{r}^{2}$ & $\begin{array}{l}\text { Added } \\
\left(\mu \mathrm{g} \mathrm{mL}^{-1}\right)\end{array}$ & $\begin{array}{l}\text { Found } \\
\left(\mu \mathrm{gLL}^{-1}\right)\end{array}$ & Recovery\% \\
\hline \multirow{8}{*}{$\mathrm{Ag}^{+}$} & \multirow{2}{*}{ Well water } & 3.996 & 0.012 & 0.999 & --- & nd & --- \\
\hline & & --- & --- & --- & 1.00 & 0.99 & 99.00 \\
\hline & \multirow{2}{*}{ Spring water } & 4.086 & 0.011 & 0.999 & --- & nd & --- \\
\hline & & --- & --- & --- & 1.00 & 0.99 & 99.00 \\
\hline & \multirow{2}{*}{$\begin{array}{l}\text { Mineral } \\
\text { drinking } \\
\text { water }\end{array}$} & 4.035 & 0.011 & 0.998 & --- & nd & --- \\
\hline & & --- & --- & --- & 1.00 & 0.98 & 98.20 \\
\hline & \multirow{2}{*}{ Tap water } & 4.080 & 0.010 & 0.999 & --- & nd & --- \\
\hline & & --- & --- & --- & 1.00 & 0.99 & 99.00 \\
\hline \multirow{8}{*}{$\mathrm{Mg}^{2+}$} & \multirow{2}{*}{ Well water } & 4.491 & 0.678 & 0.999 & --- & 1.083 & --- \\
\hline & & --- & --- & --- & 1.00 & 1.20 & 91.36 \\
\hline & \multirow{2}{*}{ Spring water } & 4.470 & 0.689 & 0.999 & --- & 1.103 & --- \\
\hline & & --- & --- & --- & 1.00 & 2.074 & 97.01 \\
\hline & \multirow{2}{*}{$\begin{array}{l}\text { Mineral } \\
\text { drinking } \\
\text { water }\end{array}$} & 4.494 & 0.701 & 0.999 & --- & 1.117 & --- \\
\hline & & --- & --- & --- & 1.00 & 2.143 & 97.30 \\
\hline & \multirow{2}{*}{ Tap water } & 4.482 & 0.662 & 0.999 & --- & 1.06 & --- \\
\hline & & --- & --- & --- & 1.00 & 2.026 & 96.63 \\
\hline
\end{tabular}

\section{Real samples - Evaluation of method}

The proposed method was applied for the determination of $\mathrm{Mg}^{2+}$ and $\mathrm{Ag}^{+}$ ions by standard addition technique in a blood serum, urine, radiology film and four different water samples including well water, spring water, tap water and mineral drinking water (Table 3). The results of blood serum and urine samples, as mentioned in the experimental section, are summarized in Table 4. The results of the determination of $\mathrm{Ag}^{+}$in radiology film sample, as mentioned in the experimental section are listed in Table 5. The recovery of spiked samples is satisfactory and reasonable, which, in view of the high selectivity provided by flame atomic absorption spectrometry, is indicative of the capability of the system in the determination of analytes in real samples. Variety in real samples including four types water, biological and radiological samples express the proposed method is applicable in complex and variously matrices.

\section{CONCLUSION}

The proposed cloud point extraction method, using ligand as a stable and fairly selective complexing agent offers a simple, rapid, inexpensive and environmentally benign methodology for preconcentration and separation of $\mathrm{Mg}^{2+}$ and $\mathrm{Ag}^{+}$in aqueous solutions. This method gives very low LOD, good RSD and was applied to the determination of trace amounts of $\mathrm{Mg}^{2+}$ and $\mathrm{Ag}^{+}$ ions in various real samples. In a full comparison of presented results in this 
paper with those previously reported, it is found that this method is superior in terms of linear range, detection limits and selectivity. For comparison, the analytical performance data of similar method reported in literature have been listed in Table 5. As it can be seen, the figures of merit of the developed method are comprisable or better than the reported methods.

Table 4 Characteristics of the standard addition curves of $\mathrm{Mg}^{2+}$ ion and its recovery in blood serum and urine samples.

\begin{tabular}{|c|c|c|c|c|c|c|c|}
\hline Samples & Sex & Slope & Intercept & $\mathrm{r}^{2}$ & $\begin{array}{c}\text { Added } \\
\left(\mu \mathrm{g} \mathrm{mL}^{-1}\right)\end{array}$ & $\begin{array}{l}\text { Found } \\
\left(\mu \mathrm{g} \mathrm{mL}^{-1}\right)\end{array}$ & Recovery\% \\
\hline \multirow{2}{*}{ Blood serum } & \multirow{2}{*}{ Female } & 4.458 & 0.476 & 0.999 & --- & 2.31 & --- \\
\hline & & --- & --- & --- & 1.00 & 3.31 & 100.0 \\
\hline \multirow{2}{*}{ Urine } & \multirow{2}{*}{ Female } & 4.491 & 0.784 & 0.999 & --- & 1.91 & --- \\
\hline & & --- & --- & --- & 1.00 & 2.91 & 100.0 \\
\hline
\end{tabular}

Table 5 Characteristics of the standard addition curve of $\mathrm{Ag}^{+}$ion and its recovery in radiology film sample.

\begin{tabular}{|c|c|c|c|c|c|}
\hline Slope & Intercept & $\mathrm{r}^{2}$ & $\begin{array}{c}\text { Added } \\
\left(\mu \mathrm{g} \mathrm{mL}^{-1}\right)\end{array}$ & Founded $\left(\mu \mathrm{g} \mathrm{mL}^{-1}\right)$ & Recovery\% \\
\hline 3.867 & 0.743 & 0.999 & --- & 28.80 & -- \\
\hline-- & --- & --- & 13.30 & 41.99 & 99.20 \\
\hline
\end{tabular}

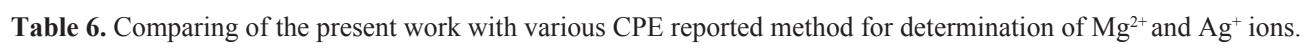

\begin{tabular}{|c|c|c|c|c|c|c|c|}
\hline Analyte & Method & Ligand & Surfactant & Linear range & D.L & $\begin{array}{l}\text { Enrichment } \\
\text { factor(Ef) }\end{array}$ & Ref. \\
\hline \multirow{2}{*}{$\mathbf{M g}^{2+}$} & CPE-FAAS & trizma-chloranilate & Triton X-114 & $5-220 \mu \mathrm{g} \mathrm{L}^{-1}$ & $0.75 \mu \mathrm{g} \mathrm{L}^{-1}$ & & [37] \\
\hline & CPE-FAAS & $\begin{array}{l}4 \text { methyl-3-((1-H-Indol-3-iyl) } \\
\text { (phenyl) methyl)) -1-H-Indol } \\
\text { (MPBIM) }\end{array}$ & Triton X-114 & $\begin{array}{c}0.007-0.200 \mu \mathrm{g} \\
\mathrm{mL}^{-1}\end{array}$ & $\begin{array}{c}1.47 \mathrm{ng} \\
\mathrm{mL}^{-1}\end{array}$ & 136.09 & $\begin{array}{l}\text { This } \\
\text { work }\end{array}$ \\
\hline \multirow{5}{*}{$\mathbf{A g}^{+}$} & CPE-FAAS & $\begin{array}{l}\text { Bis((1H-benzo[d]imidazol- } \\
\text { 2yl)methyl)sulfane (BHIS) }\end{array}$ & Triton X-114 & $2-400 \mathrm{ng} \mathrm{L}^{-1}$ & $1.9 \mathrm{ng} \mathrm{mL}^{-1}$ & 39 & [38] \\
\hline & CPE-FAAS & $\begin{array}{c}\text { 2-((2-((1H-benzo[d] } \\
\text { imidazole-2-yl)methoxy) } \\
\text { phenoxy)methyl)-1H- } \\
\text { benzo[d]imidazol (BIMPI) }\end{array}$ & Triton X-114 & $\begin{array}{c}28.0-430.0 \mu \mathrm{g} \\
\mathrm{L}^{-1}\end{array}$ & $10.0 \mu \mathrm{g} \mathrm{L}^{-1}$ & 35 & [39] \\
\hline & CPE-FAAS & $\begin{array}{l}\text { bis((1H-benzo [d] imidazol- } \\
\text { 2yl)ethyl) sulfane (BIES) }\end{array}$ & Triton X-114 & & $1.4 \mathrm{ng} \mathrm{mL}^{-1}$ & 42 & [40] \\
\hline & CPE-ETAAS & & PONPE 7.5 & $5-100-\mathrm{ng} \mathrm{L}^{-1}$ & $1.2 \mathrm{ng} \mathrm{L}^{-1}$ & 60 & [41] \\
\hline & CPE-FAAS & $\begin{array}{l}4 \text { methyl-3-((1-H-Indol-3-iyl) } \\
\text { (phenyl) methyl)) -1-H-Indol } \\
\text { (MPBIM) }\end{array}$ & Triton X-114 & $\begin{array}{c}0.007-0.200 \mu \mathrm{g} \\
\mathrm{mL}^{-1}\end{array}$ & $3 \mathrm{ng} \mathrm{mL}^{-1}$ & 40.56 & $\begin{array}{l}\text { This } \\
\text { work }\end{array}$ \\
\hline
\end{tabular}

\section{REFERENCES}

1. Welsh, P.G.; Lipton, J.; Chapman, G.A.; Podrabsky, T.L. Toxicity. Environ. Toxicol. Chem. 2000, 19, 1624.

2. Ryan, M.F.; Barbou, H. Magnesium measurement in routinepractice, Ann. Clin. Biochem. 1998, 35, 449.

3. Ai, P.Y.; Ting, G.Y.; Ling, D. Guangdong Weiliang Yuansu Kexue, 2004, 11,31

4. Grayson, M. Kirk-Othmer Encyclopedia of Chemical Technology, vol. 21, 3rd ed, Wiley, New York, 1980.

5. Smith, I.C.; Carson, B.L.; Trace Metals in the Environment, vol. 2, Ann Arbor Science Publisher's Inc. Ann Arbor, MI, 1977.
6. Ghaedi, M.; Daneshfar, A.; Shokrollahi, A.; Ghaedi, H.; Arvin Pili, F.; Ann. Chim. (Rome) 2007, 97, 971.

7. Arslan, Z.; Tyson, J. Talanta 1999, 50, 929.

8. Thuy, D.T.; Weever, D.D.; Kok, W.T.; Luan, P.; Nghi, T.V. Anal. Chim. Acta, 1994, 295, 151.

9. Kiptoo, J.K.; Ngila, J.C.; silavwe, N.D. Microchim. Acta, 2008, 160, 211.

10. Zhu, X.; Alexandratos, S.D. Microchem. J. 2007, 86, 37.

11. Prohaska, C.; Pamazal, K.; Steffan, I. Fresenius J. Anal. Chem. 2000, 367,479 .

12. Huang, C.; Hu, B. Spectrochim. Acta B 2008, 63, 437.

13. Şahan, Y., Basoglu, F., Gücer, S. Food Chem. 2007, 105, 395.

14. Zejli, H.; Hidalgo-Hidalgo de Cisneros, J.L.; Naranjo-Temsamani, I. 
Talanta 2007, 71, 1594.

15. Oliva, A.; Molinari, A.; Zuniga, F.; Ponce, P. Microchim. Acta. 2002, 140, 201.

16. Dallali, N.; Agrawal, Y.K. J. Chem. And Chem. Eng. 2004, 23, 65.

17. Soylak, M.; Cay, R.S. J. Hazard. Mater. 2007, 146, 142.

18. Giokas, D.L.; Paleologos, E.K.; Veltsistas, P.G.; Miltiades, Karayann, I. Talanta 2002, 56, 415.

19. Ghaedi, M;. Shokrollahi, A.; Niknam, K.; Niknam, E.; Derki, S.; Soylak, M. J. Hazard Mater. 2009, 168, 1022.

20. Madrakian, T.; Afkhami A.;[21] Hu, Q.; Yang, G.; Huang, Z.; Yin, J. Anal. Sci. 2003, 19, 1449

21. Shokrolahi, A.; Ghaedi,M.; Shabani, R.; Montazerozohori, M.; Chehreh, F.; Soylak, M.; Alipour, S. Food Chem. Toxicol. 2010, 48, 482.

22. Gallindo Borges, D.L.; Mesquita Silva da Veiga, M.A.; Azzolin Frescura, V.L.; Welz, B.; Jose Curtius, A. J. Anal. At. Spectrom. 2003, 18, 501.

23. Kulichenko, S.A.; Doroschuk, V.O.; Lelyushok, S.O. Talanta 2003, 59, 767.

24. Manzoori, J.L.; Bavili-Tabrizi, A. Anal. Chim. Acta 2002, 470, 215.

25. Manzoori, J.L.; Bavili-Tabrizi, A. Microchem. J. 2002, 72, 1.

26. Manzoori, J.L.; Bavili-Tabrizi, A. Microchim. Acta 2003, 141, 201.

27. Nascentes, C.C.; Arruda, M.A.Z. Talanta 2003, 61, 759.

28. Ortega, C.; Gomez, M.R.; Olsina, R.A.; Silva, M.F.; Martinez, L.D. J. Anal. At. Spectrom. 2002, 17, 530.
29. Paleologos, E.K.; Vlessidis, A.G.; Karayannis, M.I.; Evmiridis, N.P. Anal. Chim. Acta 2003, 477, 223.

30. Wuilloud, G.M.; de Wuilloud, J.C.A.; Wuilloud, R.G.; Silva, M.F.; Olsina, R.A.; Martinez, L.D. Talanta 2002, 58, 619.

31. Niknam, K.; Saberi, D.; Baghernejad, M. Phosphorus, Sulfur Silicon Relat. Elem. 2010, 185, 875.

32. Shokrollahi, A.; Shamsipur, M.; Jalali, F.; Nomani, H. Cent. Eur. J. Chem. 2009, 7, 38.

33. Shemirani, F.; Baghdadi, M.; Ramezani, M., Jamali, M.R. Anal. Chim. Acta, 2005, 534, 163.

34. Pinto, C.G.; Pavon, J.L.P.; Cordero, B.M.;Beato, E.R.; Sanchez, S.S. J. Anal. At. Spectrom. 1996, 11, 37.

35. Stalikas, C.D. Trends Anal. Chem. 2002, 21, 343.

36. Giokas, DL., Paleologos, E.K., Veltsistas, P.G., Karayannis, M.I. Talanta, 2002, 56, 415 .

37. Ahmadi, F., Niknam, K., Niknam, E., Delavari, S., Khanmohammadi, A. E-J. Chem. 2011, 8, 435.

38. Tavallali, H., Yazdandoust, S., Yazdandoust, M. Clean - Soil, Air, Water, 2010, 38, 242.

39. Ghaedi M., Shokrollahi, A., Niknam, K., Niknam, E., Najibi, A., Soylakc, M. J. Hazard. Mater, 2009, 168,1022.

40. Manzoori, J.L., Abdolmohammad-Zadeh, H., Amjadi, M. J. Hazard. Mater, 2007, 144. 458. 